\title{
Prenatal diagnosis of congenital fetal malformations medically terminated: a retrospective analysis
}

\author{
Papa Dasari, Pratima Aggrawal \\ Corresponding author: Dr. Papa Dasari, Professor, Department of Obstetrics and Gynaecology, \\ JIPMER, Puducherry, India; Email: dasaripapa@gmail.com
}

Distributed under Attribution-Non Commercial - Share Alike 4.0 International (CC BY-NC-SA 4.0)

\begin{abstract}
Objectives: The primary objective of this study is to find out demographic and clinical profile of women with congenital malformation who underwent MTP and secondary objective is to find out types of congenital malformations, risk factors and method of termination of pregnancy. Methods: This retrospective cohort involved women with congenital malformations who underwent medical termination (MTP) over a 3 year period (July 2016 to June 2019) in a tertiary care facility. Data was analysed with respect to gestational age and spectrum of malformations and results were expressed as frequencies and proportions. Results: Of the 640 women underwent MTP, 245 were for congenital fetal malformations (38.2\%). The mean age was 25 years, 95\% belonged to low socioeconomic status and from rural background and were Hindus. The most common system affected was CNS (55.5\%) followed by renal. The most common lethal anomalies were anencepahaly and hydrocephalous. Majority were diagnosed between 16 to 20 weeks and only $3 \%$ were diagnosed in first trimester. Risk factors were third and second degree consanguinity (27\%), diabetes in pregnancy (28\%) and non consumption of folic acid preconceptionally (92\%). Conclusion: The most common anomalies are largely preventable as they involved CNS and $40 \%$ were anencephaly. Non-consumption of folic acid, consanguineous marriage and diabetes mellitus were the risk factors. This suggests the need for increasing public awareness for intake of periconceptional folic acid and practice of pre-conceptional care for control of medical disorders.
\end{abstract}

Keywords: MTP, congenital fetal malformations, CNS malformations, genetic disorders, consanguineous marriage, diabetes mellitus.

Congenital fetal malformations (CFM) are structural, functional or biochemical-molecular defects present at birth and these can be lethal and in utero - diagnosis leads ultimately to elect medical termination of pregnancy. These were one of the most known causes of still births and neonatal deaths since ancient time and in the past most of anomalies were not detected early because of poor diagnostic facility. Modern days with advancement of diagnostic techniques like ultrasonography, chorionic villus sampling (CVS) and amniocentesis most anomalies are detected early in gestation at less than 20 weeks of gestation. According to Medical Termination of Pregnancy (MTP) Act, which is in place since 1971 in India pregnancy could be terminated if there is a substantial risk of the child born with physical or mental abnormalities up to 20 weeks gestational age, as it decreases women mental agony of carrying anomalous fetus to term ${ }^{1}$.

Congenital fetal malformations can be divided into three groups: lethal, severe and mild. Lethal and severe defects together constitute major congenital abnormalities, and mild constitute minor defects ${ }^{2}$. The etiology of CFM is multifactorial and has geographic variation and the cause is unknown in $50 \%$, genetic in $32-40 \%$, environmental in 5 $10 \%^{3}$. The objective of this study is to find out the sociodemographic and clinical profile of women with congenital fetal malformations who underwent MTP and

Received: $7^{\text {th }}$ September 2020, Peer review completed: $15^{\text {th }}$ November 2020, Accepted: $5^{\text {th }}$ January 2021.

Dasari P, Aggrawal P. Prenatal diagnosis of congenital fetal malformations medically terminated: a retrospective analysis. The New Indian Journal of OBGYN. 2021; 8(1): 62-8. 
secondary objectives is to find out types of congenital malformations, risk factors for congenital malformations and methods of termination.

\section{Material and methods}

The case records of women who underwent MTP for congenital fetal malformations within the perview of MTP act over a 3 year period (July 2016 to June 2019) were analysed at a tertiary care institute, JIPMER, Puducherry. Necessary permissions for retrieval of records were obtained. Data included sociodemographic profile like socioeconomic status, geographic area, and clinical data such as age, gravidity, parity, gestational age at diagnosis and type of congenital fetal malformation and method of termination. Pre-natal diagnosis was done by USG and all malformations diagnosed elsewhere were confirmed by obstetrician and or radiologist of our institute. Termination methods were adopted as per the gestational age and medical methods were employed. viz: misoprostal, misoprostal with mifepristone and extramniotic saline with or without prostaglandins. Risk factors analysed were folic acid consumption, consanguinity and family history. Descriptive statistics were used for analysis.

\section{Results}

There were 52,555 deliveries during the study period of 3

\begin{tabular}{|c|c|c|}
\hline Characteristic & Total No. 245 & Percentage (\%) \\
\hline \multicolumn{3}{|l|}{ Age in years } \\
\hline$\leq 20$ & 33 & 13.47 \\
\hline $21-25$ & 101 & 41.22 \\
\hline $26-30$ & 81 & 33.06 \\
\hline $31-35$ & 24 & 9.79 \\
\hline $36-40$ & 6 & 2.45 \\
\hline Mean age and Range & \multicolumn{2}{|c|}{ Mean age -25 years, range -18 to 40 years } \\
\hline \multicolumn{3}{|l|}{ Religion } \\
\hline Christian & 6 & 2.45 \\
\hline Hindu & 232 & 94.93 \\
\hline Muslim & 7 & 2.86 \\
\hline \multicolumn{3}{|c|}{ Obstetric score (Gravidity) } \\
\hline Primigravida & 105 & 42.86 \\
\hline Gravida-2 & 73 & 29.79 \\
\hline Gravida-3 & 44 & 17.96 \\
\hline Gravida-4 & 13 & 5.31 \\
\hline Gravida-5 & 10 & 4.08 \\
\hline Prior abortion & 60 & 20.5 \\
\hline One Abortion & 28 & 11.4 \\
\hline Two abortion & 14 & 5.7 \\
\hline Three or more abortion & 8 & 3.2 \\
\hline \multicolumn{3}{|c|}{ Gestational age at admission } \\
\hline 11 to 12 weeks & 7 & 2.86 \\
\hline $12+1$ to 16 weeks & 46 & 18.76 \\
\hline $16+1$ to 20 weeks & 192 & 78.37 \\
\hline
\end{tabular}

Table 2: Systems involved - gestational age at diagnosis

\begin{tabular}{|c|c|c|c|c|}
\hline \multirow{2}{*}{$\begin{array}{l}\text { System } \\
\text { involved }\end{array}$} & \multirow[b]{2}{*}{$\begin{array}{l}\text { First } \\
\text { trimester } \\
11+1 \text { to } 12 \\
\text { wks } \mathrm{N}=7 \\
(2.86 \%)\end{array}$} & \multicolumn{2}{|c|}{ Second trimester anomalies } & \multirow{2}{*}{$\begin{array}{l}\text { Total } \\
N=245 \\
(100 \%)\end{array}$} \\
\hline & & $\begin{array}{l}12+1 \text { to16 } \\
\text { wks } \\
N=46 \\
(18.77 \%)\end{array}$ & $\begin{array}{l}16+1 \text { to } 20 \\
\text { wks } \\
N=192 \\
(78.36 \%)\end{array}$ & \\
\hline CNS & 5 & 24 & 107 & $136(55.5 \%)$ \\
\hline CVS & - & - & 18 & $18(7.34 \%)$ \\
\hline $\begin{array}{l}\text { Lymphatic } \\
\text { system (cystic } \\
\text { hygroma) }\end{array}$ & 2 & 11 & 2 & $15(6.1 \%)$ \\
\hline $\begin{array}{l}\text { Renal and } \\
\text { urinary tract }\end{array}$ & - & 2 & 23 & $25(10.2 \%)$ \\
\hline GI anomalies & - & 4 & 4 & $8(3.26 \%)$ \\
\hline $\begin{array}{l}\text { Musculo- } \\
\text { skeletal }\end{array}$ & - & 1 & 5 & $6(2.44 \%)$ \\
\hline $\begin{array}{l}\text { Multiple organs } \\
\text { (VECTRAL) }\end{array}$ & - & 1 & 10 & $11(4.48 \%)$ \\
\hline $\begin{array}{l}\text { Genetic } \\
\text { disorders }\end{array}$ & -- & 1 & 11 & $12(4.89 \%)$ \\
\hline $\begin{array}{l}\text { Miscellaneous/ } \\
\text { Syndromes }\end{array}$ & & 2 & 12 & $14(5.71 \%)$ \\
\hline
\end{tabular}
who underwent MTP was $640(1.2 \%)$. Of the total MTPs, $245(38.3 \%)$ were for congenital fetal malformations (CFM).

Table 1 shows the demographic and clinical profile of women who underwent MTP for CFM. The age of the women ranged from 18-40 years and the mean age was 25 years and majority (41\%) were very young (21-25 years). Most of them $(95 \%)$ were Hindus and only minority were Muslims and Christians. Majority (42\%) were primigravidae $20 \%$ and $18 \%$ were second and third gravidas respectively. History of prior abortion was present in more than $20 \%$. Most common gestational age at diagnosis was between 16 to 20 weeks $(78 \%)$ and only $3 \%$ were in the first trimester between 11 and 12 weeks.

Table 2 shows congenital malformations and the system involved with respect to gestational age. There were only 7 women $(2.86 \%)$ diagnosed in first trimester with lethal anomaly and $5(71.4 \%)$ were anencephaly and 2 were cystic hygroma. The rest of the anomalies were diagnosed in the second trimester; $19 \%$ between 12 to 16 weeks and $78 \%$ between $16^{+1}$ to 20 weeks. More than $50 \%$ terminations were for CNS malformations (55.5\%) followed by renal system $(10.2 \%)$ and cardiovascular system (7.3\%). Disorders of lymphatic obstruction constituted $6 \%$ and genetic disorders accounted for $4.8 \%$

The most common CNS lethal anomalies were anencephaly (40\%) and hydrocephalous (35\%). Among those diagnosed between 12 to 16 weeks neural tube defect was the most common and hydrocephalous was most common between 16 to 20 weeks. Anencephaly constituted $40 \%$ of the lethal CNS malformations and $61 \%$ of them were diagnosed after 16 weeks and $30 \%$ between 12 to 16 weeks 
Table 3A:Type of anomalies - CNS, CVS, Lymphatic and Renal Systems

\begin{tabular}{|c|c|c|c|c|}
\hline \multirow[t]{2}{*}{ Types of congenital fetal malformations } & \multicolumn{3}{|c|}{ Gestational age in weeks } & \multirow{2}{*}{$\begin{array}{l}\text { Total number } \\
\text { \& percentage } \\
\mathrm{N}=\mathbf{2 4 5}\end{array}$} \\
\hline & $\begin{array}{l}11 \text { to } 12 \\
(\mathrm{~N}=7)\end{array}$ & $\begin{array}{l}12+1 \text { to } 16 \\
(\mathrm{~N}=46)\end{array}$ & $\begin{array}{l}16+1 \text { to } 20 \\
(\mathrm{~N}=192)\end{array}$ & \\
\hline CNS anomaly & $5(3.6 \%)$ & $24(17.6 \%)$ & $107(78.7 \%)$ & $136(55.51 \%)$ \\
\hline Neural tube defect & 5 & 21 & 53 & 79 \\
\hline Exencephaly & - & - & 1 & 1 \\
\hline Anencephaly & 5 & 16 & 33 & 54 \\
\hline Encephaloceles & - & 3 & 11 & 14 \\
\hline Meningocele & - & 1 & 5 & 6 \\
\hline Meningomyelocele & - & - & 3 & 3 \\
\hline Meningoencephalocele & - & 1 & - & 1 \\
\hline Brain/Cephalic disorder & - & 3 & 54 & 57 \\
\hline Hydrocephalus & - & 3 & 45 & 48 \\
\hline Arnold Chiari malformation & - & - & 27 & 27 \\
\hline Dandy walker syndrome & - & - & 4 & 4 \\
\hline Hydrocephalus (not specified) & - & 2 & 11 & 13 \\
\hline Hydrocephalous and spina bifida & - & 1 & 3 & 4 \\
\hline Holoprosencephaly & - & - & 5 & 5 \\
\hline CVS anomalies & - & - & 18 & $18(7.35 \%)$ \\
\hline Hypoplasia of left ventricle (single ventricle syndrome) & - & - & 7 & 7 \\
\hline Tetralogy of fallot & - & - & 6 & 6 \\
\hline Cardiac anomaly(cyanotic) & - & - & 5 & 5 \\
\hline Lymphatic obstruction (Cystic hygroma) & 2 & 11 & 2 & $15(6.1 \%)$ \\
\hline Renal system and urinary tract anomaly & - & 2 & 23 & $25(10.2 \%)$ \\
\hline B/L Multicystic kidney & - & 1 & 4 & 5 \\
\hline $\mathrm{B} / \mathrm{L}$ Renal agenesis & - & - & 5 & 5 \\
\hline Bladder outlet obstruction & - & 1 & 4 & 5 \\
\hline B/L Kidney dysplasia & - & - & 4 & 4 \\
\hline $\mathrm{B} / \mathrm{L}$ Hydronephrosis & - & - & 3 & 3 \\
\hline B/L Hydronephrosis and pulmonary hypoplasia & - & - & 2 & 2 \\
\hline Horseshoe kidney & - & - & 1 & 1 \\
\hline
\end{tabular}

Table 3B: Type of anomalies - GI, Musculoskeletal, VACTERL, Genetic disorders and Syndromes

\begin{tabular}{|c|c|c|c|c|}
\hline \multirow[t]{2}{*}{ Types of congenital fetal malformations } & \multicolumn{3}{|c|}{ Gestational age in weeks } & \multirow{2}{*}{$\begin{array}{l}\text { Total number \& } \\
\text { percentage } \\
\mathrm{N}=\mathbf{2 4 5}\end{array}$} \\
\hline & $\begin{array}{l}11 \text { to } 12 \\
(N=7)\end{array}$ & $\begin{array}{c}12+1 \text { to } 16 \\
(N=46)\end{array}$ & $\begin{array}{c}16+1 \text { to } 20 \\
(N=192)\end{array}$ & \\
\hline GIT anomaly & - & 4 & 4 & $8(3.27 \%)$ \\
\hline Diaphragmatic hernia & - & 1 & 2 & 3 \\
\hline Omphalocele & - & 2 & 1 & 3 \\
\hline Gastroschisis & - & 1 & - & 1 \\
\hline Large abdominopelvic cyst & - & - & 1 & 1 \\
\hline Musculoskeletal system & - & 1 & 5 & $6(2.45 \%)$ \\
\hline Skeletal dysplasia & - & 1 & 3 & 4 \\
\hline Long bone anomaly & - & - & 1 & 1 \\
\hline Sirenomelia \& sacral agenesis & - & - & 1 & 1 \\
\hline VACTERL anomalies & - & 1 & 10 & $11(4.48 \%)$ \\
\hline Genetic disorders & - & 1 & 11 & $12(4.89 \%)$ \\
\hline Down's syndrome & - & - & 4 & 4 \\
\hline Edward syndrome & - & - & 2 & 2 \\
\hline Inborn error of metabolism (IEM) & - & - & 3 & 3 \\
\hline Spinal muscular atrophy gene & - & - & 1 & 1 \\
\hline Myotonic dystrophy gene & - & - & 1 & 1 \\
\hline Maple syrup urine disease (MSUD) & - & 1 & - & 1 \\
\hline Miscellaneous /syndromes & - & 2 & 12 & $14(5.7 \%)$ \\
\hline Heterotaxy & - & - & 1 & 1 \\
\hline Heterotaxy and diaphragmatic hernia & - & - & 1 & 1 \\
\hline Amniotic band syndrome & - & 1 & - & 1 \\
\hline Prune belly syndrome & - & - & 1 & 1 \\
\hline Bardet Biedl syndrome & - & - & 1 & 1 \\
\hline Immune hydrops & & & 1 & 1 \\
\hline Non-immune hydrops & & 1 & 7 & 8 \\
\hline
\end{tabular}


and less than $10 \%$ in first trimester. Among 48 women with hydrocephalous only 3 were diagnosed between 12 to 16 weeks and 45 were diagnosed between 16-20 wks. Majority of hydrocephalous were due to Arnold Chiari malformation (56\%). Of the cardiac anomalies the lethal ones were single ventricle, complex cardiac malformations tetralogy of fallot which constituted one third each.. Cystic hygroma accounted for $6 \%$ and was diagnosed during first as well as second trimesters. Among the renal anomalies multicystic kidney, bilateral renal agenesis and bladder outlet obstruction were common and others like bilateral hydronephrosis and horse shoe kidney may also be lethal and may be associated with genetic disease.

Table 3 (A and B) shows the types of anomalies. $\mathrm{CDH}$, omphalocele and gastroschisis were the common anomalies and these could be diagnosed in second trimester only. Musculoskeletal anomalies constituted $2.5 \%$ and the most common anomaly was skeletal dysplasia. Genetic disorders accounted for $4.8 \%$ and the most common was Downs syndrome and it was second trimester diagnosis. VECTRAL anomalies were present in $4.5 \%$.

\begin{tabular}{ll} 
Table 4: Risk factors for CFM & \\
\hline Risk factors & Total number \\
& $\mathbf{N = 2 4 5}(\mathbf{\%})$ \\
\hline Consanguinity & $67(27.35 \%)$ \\
First degree & 1 \\
Second degree & 22 \\
Third degree & 44 \\
\hline Diabetes Mellitus & $69(28.16 \%)$ \\
Overt diabetic & 22 \\
GDM & 47 \\
\hline Hypothyroidism & $13(5.31 \%)$ \\
\hline Conception after ovulation induction & $5(2.04 \%)$ \\
\hline Previous baby Congenital malformation & $13(5.31 \%)$ \\
\hline Pre-conceptional folic acid & \\
Not taken & $226(92.24 \%)$ \\
Taken & $19(7.76 \%)$ \\
\hline
\end{tabular}

guineous marriage was the risk factor in one quarter of the CFM (27.3\%) and third degree consanguinity emerged as the most common rather than first degree. Diabetes mellitus was the risk factor in another quarter (28\%) and GDM association was the most common. Prior history of CFM was present in 5\% and another 5\% were associated with hypothyroidism. History of pre conceptional consumption of folic acid was present only in $8 \%$.

Method of MTP is shown in table 5. All pregnancies were successfully terminated by medical methods. Majority were terminated by sublingual misoprostal alone (36\%) and $20 \%$ extra-amniotic prostadin alone and $6 \%$ by extraamniotic saline alone. The rest required combination of

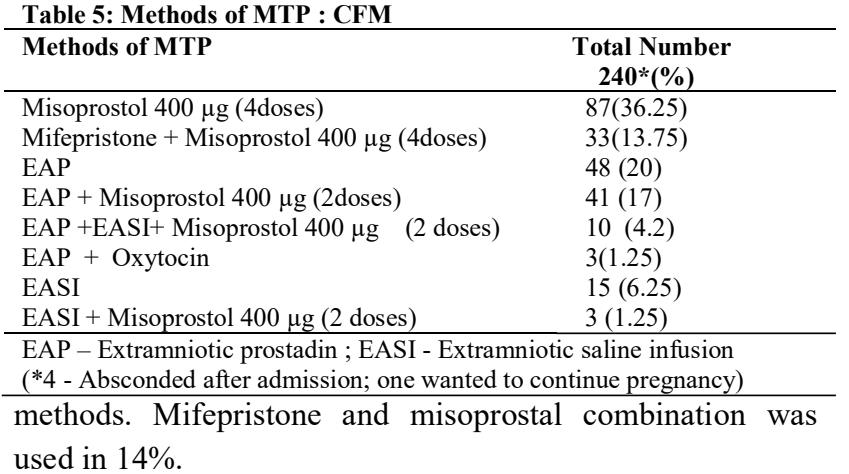

\section{Discussion}

The timely diagnosis and management of lethal congenital fetal malformations is one of the aims of antenatal care. Every obstetrician should be able to advice on this aspect and should be able to offer counseling and management services. The incidence of lethal congenital malformations varies from place to place and the time of diagnosis also varied depending on the socioeconomic status, accessibility to quality antenatal care. In India the incidence of lethal anomalies varies and a recent study published reported $45 \%$ of the anomalies ending up in MTP ${ }^{4}$. This study reported the most common age group as 21-25 years (49\%) and history of consanguinity was present in $24 \%$. In the current study which included women who underwent MTP for CFM, history of consanguinity was present in $27 \%$ and the most common age group was 21-25 years as this is the commonest age group of bearing pregnancy. The prevalence of congenital anomaly by prenatal diagnosis was reported to be 10.98 per 1000 births and MTP rate was 4.39 per 1000 births in a large Indian cohort. In the present study the rate of termination was 12 per 1000 which is high when compared to the study of Prajkta Bhide and colleagues ${ }^{9}$.

Whenever a fetal lethal anomaly was diagnosed most women elect to terminate the pregnancy but in a cohort of 20 fetal lethal anomalies only $60 \%$ chose for termination ${ }^{5}$. Counseling is important aspect which should include the neonatal, childhood problems and morbidity and mortality of the condition. In the present study also 5 women deferred to undergo MTP and continued the pregnancy. In these cases the live born need palliative perinatal care which should be individualised for each condition. Anomaly scan is most commonly performed between 18 to 20 weeks in many centres and this is the reason why most of the anomalies were diagnosed between 16-20 weeks in the current study and other studies. There is no universally accepted classification of congenital malformation. EUROKOT 
mainly defined to categorise for ICD ${ }^{6}$ and the etiological classification is also not advocated as in more than $50 \%$ of anomalies it is difficult to establish the cause of anomaly ${ }^{7}$.

The most common lethal anomalies were that of CNS and anencephaly and hydrocephalous were the commonest which was also found in the study of Lavanya $\mathrm{S}$ et al ${ }^{4}$. The recommendations for severe abnormalities like anencephaly and hydrocephalous is straightforward but isolated agenesis of corpus callosum and mild ventriculomegaly may pose problem due to progression and regression (RCOG) ${ }^{8}$.

Cardiac defects were reported to be most common in the study done at Pune university ${ }^{9}$. Critical cardiac defects include complex cardiac defects, transposition of great arteries, coarctation of aorta, pulmonary atresia, tetralogy of fallot and single ventricle etc. In the present study single ventricle and tetralogy of fallot and complex cardiac defects were the reasons for termination of pregnancy. Pregnancy continuation and surgical correction may be undertaken but the prognosis is guarded for many of the critical cardiac defects and hence counseling and decision for termination are the most important factors and CHD are classified in to life threatening $\mathrm{CHD}$, clinically significant $\mathrm{CHD}$ and clinically non-significant CHD. ${ }^{10}$

Renal system anomalies constituted $10.2 \%$ of CFM that underwent MTP and the majority were diagnosed after 16 weeks. The most common renal anomalies included bilateral multi-cystic kidneys, renal agenesis, and outlet obstruction. Renal anomalies are associated with syndromes and even if non syndromic they are associated with genetic disorders in $2 \%$. Saiswath and colleagues found mutations in the RET, BMP4, FRAS1, and FREM2 genes in 40 patients with CAKUT anomalies ${ }^{11}$. Horseshoe kidney is associated with trisomy 18 and most fused kidneys have obstructive uropathy and repair is complicated in the neonatal period.

The most common life-threatening gastro-intestinal anomalies in the neonatal period include congenital diaphragmatic hernia, gastroschisis, oesophageal atresia, tracheao-oesophageal fistula, exompholos, anorectal malformation, Hirschsprung disease and intestinal atresia. These can be dealt by emergency neonatal surgery but the mortality is more than $50 \%$ in LMICs. Mortality rate for gastroschisis is reported as 75 to $100 \%$ in LMICs and $4 \%$ in HICs. Parental counselling is an important aspect in decision making. Mortality rates for $\mathrm{CDH}$, gastroschisis were $47 \%, 42 \%$ in MICs and $20 \%$ and $3.7 \%$ in HICs respectively ${ }^{13}$. This is mainly because of the availability of expert paediatric surgery facilities and availability of dedicated neonatal intensive care units.

Thanatophoric dysplasia is the most common lethal skeletal dysplasia complicating 1:10000 pregnancies and skeletal dysplasia occurs 1 in 4000 births. Fetal skeleton is visualised during USG by 14 weeks and foetuses showing $<5^{\text {th }}$ percentile of femoral and humoral length need to be evaluated for skeletal dysplasia by molecular tests ${ }^{14}$. In the current study there were 6 women with skeletal dysplasia and one was diagnosed before 16 weeks and 5 between 1620 weeks. VACTERL (Vertebral, Anorectal, Cardiovascular, Tracheoesophageal, Oesophagealagenesis, Renalor Radial and Limb defects) are diagnosed when anomalies involve at least three of the systems together in a single fetus. In the present study VACTERL constituted $4.5 \%$. The incidence is reported to be varying from 1 in 10,000 to 40,000 . And some of the anomalies may be corrected after birth ${ }^{15}$. Here women may have chosen to undergo termination after counseling. Termination for confirmed genetic diseases was undertaken in approximately $5 \%$ and out of these the most common was Down's syndrome. The largest study which analysed 26,950 amniocenteses found $1.54 \%$ to have chromosomal anomaly. Ninety five percent of pregnancies with autosomal anomaly (Trisomy 21,18,13) underwent termination ${ }^{16}$. A Japanese study reported that termination rate of $75 \%$ for chromosomal anomaly and the most common indication was trisomy $21^{17}$. Some of the rare disorders which underwent termination in this cohort were heterotaxy with diaphragmatic hernia, Prune belly syndrome, amniotic band syndrome, Bardet Biedl Syndrome, severe immune hydrops and non-immune hydrops. The discussion of each of these is beyond the scope of the article. A retrospective study on immune hydrops diagnosed after 20 weeks reported a survival rate of $48 \%$ and prenatal diagnosis was possible only in $56 \%{ }^{18}$. Even though prenatal diagnosis is possible many factors influence the decision for termination of pregnancy ${ }^{19}$.

In the last decade the recommendations world over are 11-14 weeks NT scan and 18-20/23 weeks anomaly scan to detect CFM and the detection rates vary depending up on the level of trained sonologists, the availability of high resolution ultrasound and the detection rates of $48 \%$ and $92 \%$ are reported during first and second trimester scan ${ }^{20}$. Detection rate of $84 \%$ of anomalies in 11-14 weeks scan was reported by Becker and colleagues ${ }^{22}$. It is also important to appraise that late onset anomalies which may be lethal and of poor prognosis like late onset hydrocephalous due to Arnold chiari malformation, Dandy Walker syndrome, intracranial 
The New Indian Journal of OBGYN. 2021 (July-December);8(1)

haemorrhage ${ }^{23}$. Lethal skeletal anomaly like achondroplasia may be detected after 27 weeks of pregnancy ${ }^{24}$. A third trimester USG for anomalies is reported to detect $15 \%$ of structural malformations when first and second trimester report was normal ${ }^{25}$. As per MTP Act, these anomalies though sometimes lethal, pregnancy cannot be terminated as it is beyond permitted legal gestational age. Hence during antenatal care one needs to explain the limitations of first and second trimester scan and counsel women accordingly. Each facility should have their detection rate of CFM and type of anomalies, especially lethal anomalies so as to help the clinician in counselling the couple regarding decision making. Health education regarding the causative factors and prevention is also an important aspect which needs to be incorporated in to counselling during prenatal diagnosis especially before making a decision for termination.

The major risk factor for development of congenital malformation involving CNS and other major systems is folic acid deficiency which is well established in the literature since many decades. It is proved that with supplementation the incidence decreased and recommendations are in place ${ }^{26}$. Still $92 \%$ did not take preconceptional folic acid. This calls for strict implementation of awareness programmes in prenatal health care. The other risk factor is the association of consanguineous marriage and congenital anomaly which is also found to be a significant factor for CFM ${ }^{27}$. In the present study, history of consanguineous marriage was present in $27 \%$. Consanguineous marriages are practiced by $10 \%$ of world's population and found to increase the congenital malformations as well as other disorders like diabetes, cardiovascular disorders, obesity and infertility ${ }^{28,29}$. Other association with CFM include diabetes mellitus, hypothyroidism of which uncontrolled diabetes and its association is also well documented. The commonest anomalies in pregestational diabetes were cardiovascular and central nervous system anomalies ${ }^{30}$. In the current study $28 \%$ were associated with diabetes mellitus.

\section{Conclusion}

Congenital fetal malformations constituted one third of MTPs undertaken at a tertiary care institute. The most common anomalies are largely preventable as they involved CNS and $40 \%$ were anencephaly. Non-consumption of folic acid, consanguineous marriage and diabetes mellitus were the risk factors. This suggests the need for increasing public awareness for intake of periconceptional folic acid and practice of pre-conceptional care for control of medical disorders.

\section{Conflict of interest: None. Disclaimer: Nil.}

\section{References}

1. Ministry of Health and Family Welfare India. The Medical Termination of Pregnancy Act 1971. New Delhi: GOI. 2016. Available at: https://main.mohfw. gov.in/acts-rules-and-standards-health-sector/acts/mtpact-1971

2. Czeizel AE. Birth defects are preventable. Int J Med Sci. 2005; 2(3): 91-2.

3. Liu L, Johnson HL, Cousens S, Perin J, Scott S, Lawn JE, et al. Global, regional, and National causes of child mortality: an updated systematic analysis for 2010 with time trends since 2000. The Lancet. 2012; 379(9832): 2151-61.

4. Sowmyanarayanan L, Vuppu S. A two-year study of patterns and prevalence of congenital malformations. IJRCOG. 2017; 7: 114-8.

5. Breeze AC, Lees CC, Kumar A, Missfelder-Lobos HH, Murdoch EM. Palliative care for prenatally diagnosed lethal fetal abnormality. Arch Dis Child Fetal Neonatal Ed. 2007; 92(1): F56-F58.

6. Lechat MF, Dolk H. Registries of congenital anomalies: EUROCAT. Environ Health Perspect. 1993;101(Suppl 2):153-7.

7. Wellesley D, Boyd P, Dolk H, Pattenden S. An aetiological classification of birth defects for epidemiological research. J Med Genet. 2005; 42(1): 54-7.

8. RCOG guidelines: Termination of pregnancy for fetal abnormality in England, Scotland and Wales. Report of a working party. 2010 Available at: www.rcog. org. uk

9. Bhide P, Gund P, Kar A. Prevalence of Congenital Anomalies in an Indian Maternal Cohort: Healthcare, Prevention, and Surveillance Implications. PLoS One. 2016;11(11):e0166408.

10. Yun SW. Congenital heart disease in the newborn requiring early intervention. Korean J Pediatr. 2011; 54(5):183-91.

11. Saisawat P, Tasic V, Vega-Warner V, Kehinde EO, Günther B, Airik R, et al. Identification of two novel CAKUT-causing genes by massively parallel exon resequencing of candidate genes in patients with 
The New Indian Journal of OBGYN. 2021 (July-December);8(1)

unilateral renal agenesis. Kidney Int. 2012 Jan; 81(2):196-200.

12. Wright NJ, Zani A, Ade-Ajayi N. Epidemiology, management and outcome of gastroschisis in subSaharan Africa: results of an international survey. Afr J Paediatr Surg. 2015;12:1-6.

13. Wright NJ, Global Paed Surg Research Collaboration. Management and outcomes of gastrointestinal congenital anomalies in low, middle and high income countries: protocol for a multicentre, international, prospective cohort study. BMJ Open. 2019; 9(8): e030452.

14. Krakow D, Lachman RS, Rimoin DL. Guidelines for the prenatal diagnosis of fetal skeletal dysplasias. Genet Med. 2009;11(2):127-33.

15. Solomon BD. VACTERL / VATER Association. Orphanet Journal of Rare Diseases. 2011; 6: 56.

16. Vincent VA, Edwards JG, Young SR, Nachtigal M. Pregnancy termination because of chromosomal abnormalities: a study of 26,950 amniocenteses in the southeast. South Med J. 1991; 84(10):1210-3.

17. Nishiyama M, Sekizawa A, Ogawa K, Sawai H, Nakamura H, Samura O, et al. Factors affecting parental decisions to terminate pregnancy in the presence of chromosome abnormalities: a Japanese multicenter study. Prenat Diagn. 2016 Dec; 36(12):1121-6.

18. Santo S, Mansour S, Thilaganathan B, Homfray $T$, Papageorghiou A, Calvert S, et al. Prenatal diagnosis of non-immune hydrops fetalis: what do we tell the parents? Prenat Diagn. 2011 Feb; 31(2):186-95.

19. Gedikbaşı A, Gül A, Oztarhan K, Akın MA, Sargın A, Ozek S, et al. Termination of pregnancy and reasons for delayed decisions. J Turk Ger Gynecol Assoc. 2010 Mar 1;11(1): 1-7.

20. Taipale P, Ammälä M, Salonen R, Hiilesmaa V. Twostage ultrasonography in screening for fetal anomalies at 13-14 and 18-22 weeks of gestation. Acta Obstet Gynecol Scand. 2004 Dec; 83(12):1141-6.

21. Souka AP, Pilalis A, Kavalakis I, Antsaklis P, Papantoniou N, Mesogitis S, et al. Screening for major structural abnormalities at the 11- to 14-week ultrasound scan. Am J Obstet Gynecol. 2006 Feb;194(2): 393-6.

22. Becker R, Wegner RD. Detailed screening for fetal anomalies and cardiac defects at the $11-13$-week scan. Ultrasound Obstet Gynecol. 2006; 27: 613-8.
23. D'Addario V, Pinto V, Di Cagno L, Pintucci A. Sonographic diagnosis of fetal cerebral ventriculomegaly: an update. J Matern Fetal Neonatal Med. 2007 Jan; 20(1):7-14.

24. Schramm T, Gloning KP, Minderer S, Daumer-Haas C, Hörtnagel K, Nerlich A, et al. Prenatal sonographic diagnosis of skeletal dysplasias. Ultrasound Obstet Gynecol. 2009 Aug; 34(2):160-70.

25. Manegold G, Tercanli S, Struben H, Huang D, Kang A. Is a routine ultrasound in the third trimester justified ? Additional fetal anomalies diagnosed after two previous unremarkable ultrasound examinations. Ultras chall Med. 2011; 32(4):381-6.

26. Temel S, van Voorst SF, Jack BW, Denktas S, Steegers EA. Evidence-based preconceptional lifestyle interventions. Epidemiol Rev. 2014; 36:19-30.

27. Hamamy $H$, Antonarakis SE, Cavalli-Sforza LL, Temtamy S, Romeo G, Kate LP, et al. Consanguineous marriages, pearls and perils: Geneva International Consanguinity Workshop Report. Genet Med. 2011 Sep;13(9): 841-7.

28. Ameen SK, Alalaf SK, Shabila NP. Pattern of congenital anomalies at birth and their correlations with maternal characteristics in the maternity teaching hospital, Erbil city, Iraq. BMC Pregnancy Childbirth. 2018;18(1): 501.

29. Oniya O, Neves K, Ahmed B, Konje JC. A review of the reproductive consequences of consanguinity. Eur J Obstet Gynecol Reprod Biol. 2019; 232: 87-96.

30. Mironiuk M, Kietlińska Z, Jezierska-Kasprzyk K, Piekosz-Orzechowska B. A class of diabetes in mother, glycemic control in early pregnancy and occurrence of congenital malformations in newborn infants. Clin Exp Obstet Gynecol. 1997; 24(4):193-7.

\footnotetext{
Papa Dasari ${ }^{1}$, Pratima Aggrawal ${ }^{2}$

${ }^{1}$ Professor, Department of Obstetrics and Gynaecology, JIPMER, Puducherry, India; ${ }^{2}$ Senior Medical Officer, Postpartum Programme, Department of Obstetrics and Gynaecology, JIPMER, Puducherry, India.
} 